\title{
How Bovine Livestock Affects Seed Rain in Subtropical Climate Forest
}

\author{
Maureen de Moraes Stefanello ${ }^{1}$, Ana Paula Moreira Rovedder ${ }^{2}$, Roselene Marostega Felker ${ }^{2}$, \\ Matheus Degrandi Gazzola ${ }^{1}$, Betina Camargo ${ }^{1}$, Bruna Balestrin Piaia ${ }^{3}$, Jhonitan Matiello ${ }^{3}$, Djoney Procknow ${ }^{1}$, \\ Rodrigo Pinto da Silva ${ }^{2}$, Aline Peccatti ${ }^{1} \&$ Jéssica Puhl Croda $^{3}$ \\ ${ }^{1}$ Postgraduate Program in Agricultural Engineering, Federal University of Santa Maria, Santa Maria, RS, Brazil \\ ${ }^{2}$ Forest Science Department, Federal University of Santa Maria, Santa Maria, RS, Brazil \\ ${ }^{3}$ Postgraduate Program in Forest Engineering, Federal University of Santa Maria, Santa Maria, RS, Brazil \\ Correspondence: Ana Paula Moreira Rovedder, Recovery of Degraded Areas Studies and Research Group, \\ Forest Science Department, Federal University of Santa Maria, 1000, Roraima Ave, 44 Building, Office 5250, \\ Camobi Burgh, CEP: 97105-900, Santa Maria, RS, Brazil. Tel: 55-553-220-8444 ext. 24. E-mail: \\ neprade@gmail.com
}

Received: April 14, 2019

Accepted: May 23, 2019 Online Published: July 15, 2019

doi:10.5539/jas.v11n10p240

URL: https://doi.org/10.5539/jas.v11n10p240

The research is financed by Coordenação de Aperfeiçoamento de Pessoal de Nivel Superior-CAPES.

\begin{abstract}
Seed rainfall may be one of the mechanisms most impacted by livestock production in forest remnants. The trampling and cattle grazing alter dynamics, structure and floristic composition of the forest. The present work characterized the seed rainin forest remnants and the possible impacts of the presence and the management regime with different cattle stocks in the Pampa biome, southern region of Brazil. We compared three areas in Seasonal Forest remnants with a management history of 43 years: cattle exclusion area (A1); area with a cattle stock of $0.5 \mathrm{ua} \mathrm{ha}^{-1}$ (A2); and area with cattle stock of $1.0 \mathrm{ua} \mathrm{ha}^{-1}$ (A3). The seed rain was collected quarterly in 16 collectors $\left(1 \times 1 \mathrm{~m}^{2}\right)$ per area for 24 months. The seeds were counted and identified according to external morphological characteristics, habit and dispersion syndrome. Shannon diversity index, submitted to the Hutcheson test, Pielou evenness, expected diversity and floristic similarity were determined. The results indicated that the impacts caused by livestock to seed rain were more significant in A3 where a quantitative reduction in the number of seeds was observed, probably due to the low number of plant individuals that make up the community.
\end{abstract}

Keywords: animal stocking, cattle breeding, dispersal syndrome, ecological indexes, pampa biome

\section{Introduction}

The horizontal distribution of a particular species of the forest community depends on its colonization success, determined by the establishment and dispersion of its propagules (Chazdon, 2014). In this way, the relationships that plant individuals establish with the environment and with anthropic interventions can compromise the colonization and establishment of species (Hutchings, 1989; Begon et al., 2006).

Among potentially impacting economic activities in forest remnants, extensive livestock farming may hinder the establishment and development of natural regeneration (Michels et al., 2012; Brancalion et al., 2016), altering the ecological dynamics and community composition (Marchior, 2004; Eaton et al., 2016; Araújo et al., 2017).

Cattle may compromise the conservation of forest remnants by consuming flowers and seeds (Eaton et al., 2016). Cattle indirectly affect the interaction with local dispersers by modifying floral traits (Vázquez, 2002) and their diet overlaps (Eaton et al., 2016). In addition, trampling can compact the soil and hamper the establishment of natural regeneration (Pillar \& Quadros, 1997; Sampaio \& Guarino, 2007).

Knowledge of the floristic composition and the dispersion syndromes enables understanding the structure and successional stage of the vegetation (Chazdon, 2014), in addition to the degree of conservation or perturbation of the environment (Pinã-Rodrigues \& Aoki, 2014; Capellesso et al., 2015). Therefore, characterizing seed rain in 
foresta is fundamental for understanding recruitment processes, abundance, spatial distribution, density and species richness (Vieira \& Gandolfi, 2006).

The southern region of Brazil differs from the rest of the territory because of its subtropical climate. Its paleoclimatic history generated peculiar characteristics of phytophysiognomies in the two biomes of its range: Atlantic Forest and Pampa. There are mosaics of well-defined country and forest vegetation in both biomes. The presence of country vegetation enabled the development of cattle raising activity, especially in the Pampa biome. Its importance is not only economic, but also sociocultural.

The Pampa biome is currently the second most threatened in Brazil and there is a lack of scientific studies that can support restoration and sustainable management plans (Roesch et al., 2009).

The forest remnants are impacted by the advancing commodity productive area, mainly soybean crops, with a reduction in remnant size and connectivity between habitats (Silveira et al., 2017). In spite of this, they present fundamental ecosystem services; most of the springs and water courses of the biome are found in the forest remnants, in addition to serving as refuges for wild fauna and being maintainers of the floristic diversity, its products and services (Rovedder et al., 2016).

In view of the above, the present work aimed to characterize the seed rain in forest remnants in the Pampa biome of southern Brazil, verifying the possible impacts caused by the presence of cattle inside this forest.

\section{Material and Methods}

The study was carried out in a Seasonal Forest remnant in the Pampa biome, Rio Grande do Sul state, in the southern region of Brazil. The region presents Oxisols in association with Regosols and Gleisols (Streck et al., 2018; EMBRAPA, 2013). The altitudes range between 50 and 200 masl. The climate is "Cfa" according to the Köppen classification, subtropical humid, without a dry season, with an average annual temperature of $22{ }^{\circ} \mathrm{C}$. The average annual precipitation varies between 1300 and $1800 \mathrm{~mm} \mathrm{year}^{-1}$, with higher values recorded in winter (Alvares et al., 2013).

The vegetation cover is composed of fields and seasonal forests (Marchiori, 2004). The socioeconomic profile is predominantly characterized by small and medium-sized rural properties, based on the commercial cultivation of soybean, corn and extensive livestock farming (Instituto Brasileiro de Geografia e Estatística [IBGE], 2014).

\subsection{Characterization and Usage History of the Study Area}

The property has belonged to the same family for 49 years, which enabled gathering the management history of the place. The remnant forest is located at the coordinates $28^{\circ} 16^{\prime} 42.14^{\prime \prime} \mathrm{S} ; 55^{\circ} 13^{\prime} 14.14^{\prime \prime} \mathrm{W}$ and has $57 \mathrm{ha}$, with eight springs and water courses that flow into the Piratini River, a tributary of the Uruguay River. In 1975, the remainder was divided into three areas (Figure 1), which in the present study configured into the following treatments:

Area 1 (A1): part of the forest remnant surrounded and isolated from the entrance of cattle 43 years ago to preserve springs. In the present study we have considered it as a reference area.

Area 2 (A2): part of the forest remnant managed with an animal stock of $0.5 \mathrm{ua} \mathrm{ha}^{-1}$ for 43 years.

Area 3 (A3): part of the forest remnant managed with an animal stock of $1 \mathrm{ua} \mathrm{ha}^{-1}$ for 43 years. 


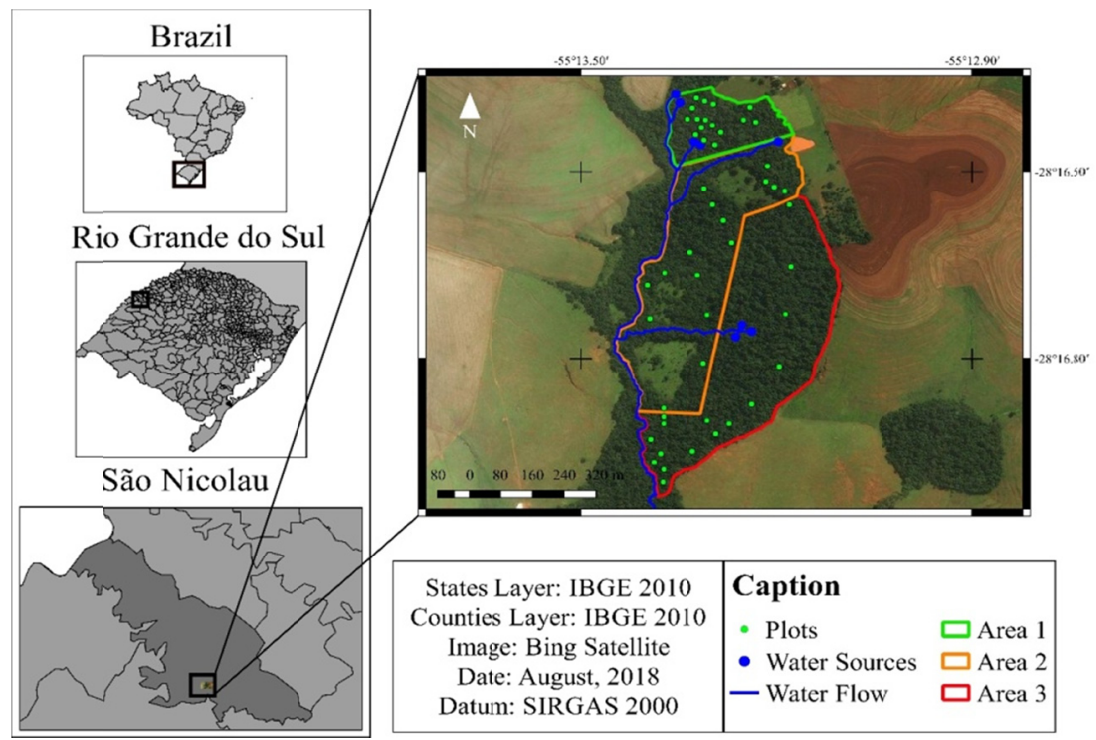

Figure 1. Remaining subtropical forest with delimitations of the study areas (A1, A2 and A3), southern Brazil

\subsection{Sampling}

A grid of $25 \mathrm{~m}^{2}(5 \times 5 \mathrm{~m})$ was superimposed on the remnant. We established transects accompanying the toposequencing for each area, in which 16 sample plots were drawn in each area. We georeferenced the central points of each plot and installed a seed rain catch per plot, totaling 16 collectors/area. Each collector $\left(1 \mathrm{~m}^{2}\right)$ was fixed to $20 \mathrm{~cm}$ of soil height. The collectors located in areas A2 and A3 were surrounded with barbed wire to prevent livestock access.

The material was collected quarterly for 24 months, from January 2015 to December 2016. Seed and fruit sorting was carried out at the Núcleo de Estudos e Pesquisas em Recuperação de Áreas Degradadas (NEPRADE) from Universidade Federal de Santa Maria, Brazil.

We performed luminosity readings with a HCVET HT-8318 digital luximeter at ground level and quarterly, considering the extremities and center of the sample plot, adding five readings per plot (Table 1).

Table 1. Luminosity rate in subtropical forest area excluding livestock (A1); (A2) and stock at 1.0 ua ha $^{-1}$ (A3), south of Brazil

\begin{tabular}{llll}
\hline Area & A1 & A2 & A3 \\
\hline Lum (lux) & $249.60 \mathrm{a}^{*}$ & $389.04 \mathrm{~b}$ & $328.1 \mathrm{~b}$
\end{tabular}

Note. Abbrev. Lum (luminosity in lux). * Values not followed by the same letter in the line differed significantly by Student's t test $(\mathrm{P}<0.05)$.

\subsection{Data Analysis}

We counted and identified the collected seeds according to external morphological characteristics and taxonomic classification at the family, gender and species levels. When identification was not possible, the propagules were grouped into morphospecies (Venzke et al., 2014; Piña-Rodrigues \& Aoki, 2014; Sccoti et al., 2016). We used the term morphospecies during the course of the work for the sum of identified and unidentified species in order to standardize the nomenclature.

The dispersion syndromes were classified according to Van Der Pijl (1982) as: zoochoric for those that presented dispersion characteristics by the frugivorous fauna, especially drupaceous fruits, berries and seeds with aril; anemochoric, when they presented structures or wings that enabled the propagules to glide; or autochoric, when the structure of the fruit presented a mechanical dispersion characteristic such as an "explosion".

The Shannon diversity index and Pielou evenness were calculated (Magurran, 1988). The Shannon diversity values (logarithmic basis) were compared by the Hutcheson test, at 5\% probability of error (Hutcheson, 1970). 
In relation to the total number of seeds, the assumptions of normality and the distribution of errors were verified by the Shapiro-Wilk and Bartlett test.

When the assumptions were not met, the non-parametric Kruskal-Wallis test $(\mathrm{p}<0.05)$ was performed using the Action software (Equipe Estatcamp, 2014). The rarefaction curve was elaborated with a $95 \%$ probability of confidence (Gotelli \& Colwell, 2001) and the similarity between areas, we used cluster analysis with Jaccard similarity measures (Müeller-Dombois \& Ellenberg, 1974) both analysis were performed in PAST software, version 1.79 (Hammer et al., 2001).

\section{Results}

\subsection{Morphospecies Distribution}

20,661 propagules were sampled from January to December 2015, distributed in 126 morphospecies (identified and unidentified species), considering the three study areas (A1, A2 and A3) (Figure 2). We collected 18,012 propagules of 136 morphospecies in 2016, considering the three study areas (Figure 2).

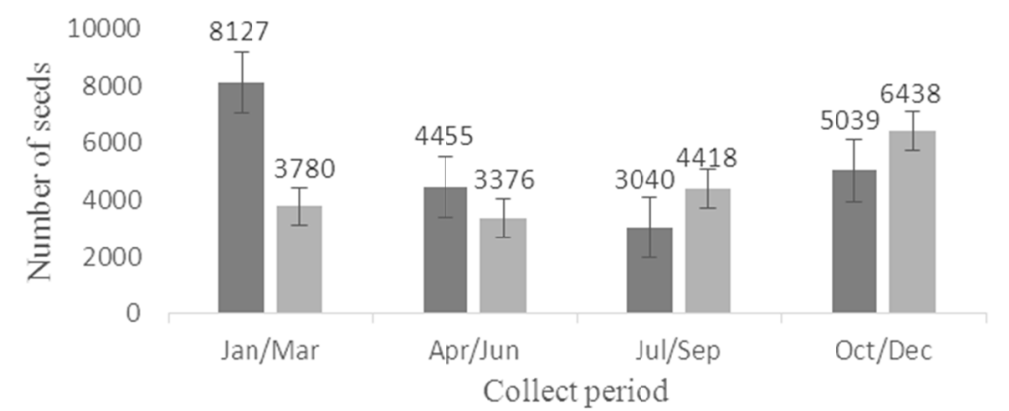

घ2015 $\mathbf{\square} 2016$

Figure 2. Total number of seed rain propagules during 24 months (2015 and 2016) in a Subtropical Forest, southern Brazil

We counted 59 morphospecies in A1 in 2015. Ilex paraguariensis, Cordia trichotoma, Ficus luschnathiana and Apuleia leiocarpa accounted for $38.12 \%$ of the total collected seeds. A2 presented 53 morphospecies. Helietta apiculata, C. trichotoma, I. paraguariensis and Jacaranda micrantha added $41.77 \%$ of seeds collected. A3 presented 60 morphospecies, with C. trichotoma, A. leiocarpa and F. luschnathiana, accounting for $45.93 \%$ of the total. In 2015, the number of seeds collected in the three study areas did not statistically differ by the Kruskal-Wallis test $(\mathrm{p}<0.05)$ (Table 2).

Table 2. Seed rain (2015 and 2016) in seasonal forest with livestock excluded (A1); 0.5 ua ha ${ }^{-1}$ of livestock capacity (A2) and 1.0 ua ha ${ }^{-1}$ of livestock capacity (A3) in South Brazil

\begin{tabular}{lll}
\hline \multirow{2}{*}{ Area } & \multicolumn{2}{c}{ Number of seeds } \\
\cline { 2 - 3 } & 2015 & 2016 \\
\hline A1 & $6896 \mathrm{a}^{*}$ & $8266 \mathrm{a}$ \\
A2 & $8790 \mathrm{a}$ & $5579 \mathrm{ab}$ \\
A3 & $4975 \mathrm{a}$ & $4157 \mathrm{~b}$ \\
\hline
\end{tabular}

Note. *Differences of letters in the column indicate that there is significant difference at the level of $5 \%$ probability of error by the Kruskal-Wallis test.

In 2016, A1 presented 51 morphospecies. The species with the highest number of seeds collected were $C$. trichotoma, Balfourodendron riedelianum, A. leiocarpa and F. luschnathiana, accounting for $39.04 \%$ of the total. A2 presented 57 morphospecies. The species with the highest number of seeds were C. trichotoma, Cedrela fissilis, Cordia americana, Luehea divaricata and F. luschnathiana, accounting for $33.77 \%$ of the total. A3 presented 50 morphospecies, among which C. trichotoma, Brunfelsia australis and C. fissilis added $32.64 \%$ of the total collected seeds. In 2016, the number of seeds sampled at A1 differed significantly from A3 by the Kruskal-Wallis test $(\mathrm{p}<0.05)$ (Table 2). 
It should be noted that $C$. trichotoma presented 3145 seeds in 2015, and 2636 seeds in 2016, being the most abundant species in the seed rain in the three areas for the two years of the study.

Lifestyle and Dispersion Syndrome: Seeds of arboreal tree species predominated in the two years of evaluation in all areas (45\% in 2015 and $47 \%$ in 2016). The predominant dispersion syndrome was zoochoric in both evaluation years in the three study areas (Figure 3).

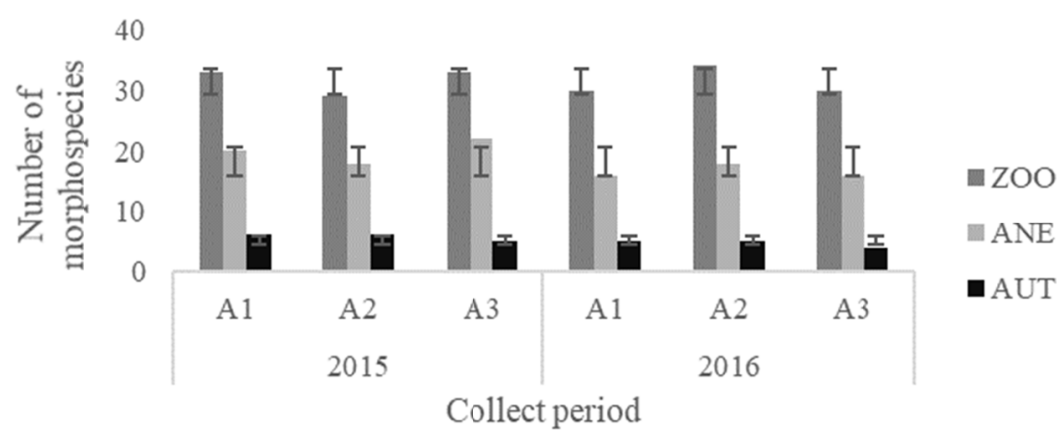

Figure 3. Number of morphospecies with zoochoric (ZOO), anemochoric (ANE) and autochoric (AUT) morphospecies present in the seed rain in a subtropical forest area with cattle exclusion (A1); stock rates of 0.5 ua ha ${ }^{-1}$ (A2) and 1.0 ua ha $^{-1}$ (A3), southern Brazil

\subsection{Ecological Indices}

The Shannon diversity index did not show significant differences between the three study areas in each period (2015 and 2016), by the Hutcheson test at 5\% probability of error (Table 3). Figure 4 shows the expected seed rainfall richness for each study area.

Table 3. Diversity indices for seed rain in 2015 and 2016 in the three study areas: forest area excluding livestock (A1); with a stock of 0.5 ua ha ${ }^{-1}$ (A2) and a stock of 1.0 ua ha $^{-1}$ (A3) in Subtropical Forest, southern Brazil

\begin{tabular}{llllllll}
\hline \multirow{2}{*}{ Indexes } & \multicolumn{4}{c}{2015} & & \multicolumn{3}{c}{2016} \\
\cline { 2 - 3 } & A1 & A2 & A3 & & A1 & A2 & A3 \\
\hline Shannon $(\mathrm{H})$ & $3.263 \mathrm{a}^{*}$ & $3.068 \mathrm{a}$ & $3.000 \mathrm{a}$ & & $3.193 \mathrm{a}$ & $3.356 \mathrm{a}$ & $3.231 \mathrm{a}$ \\
Equability $(\mathrm{J})$ & 0.8002 & 0.7727 & 0.7327 & & 0.8122 & 0.8302 & 0.8259 \\
\hline
\end{tabular}

Note. *Equal letters on the same line indicate that there is no significant difference at the $5 \%$ probability level of error by the Hutcheson test.

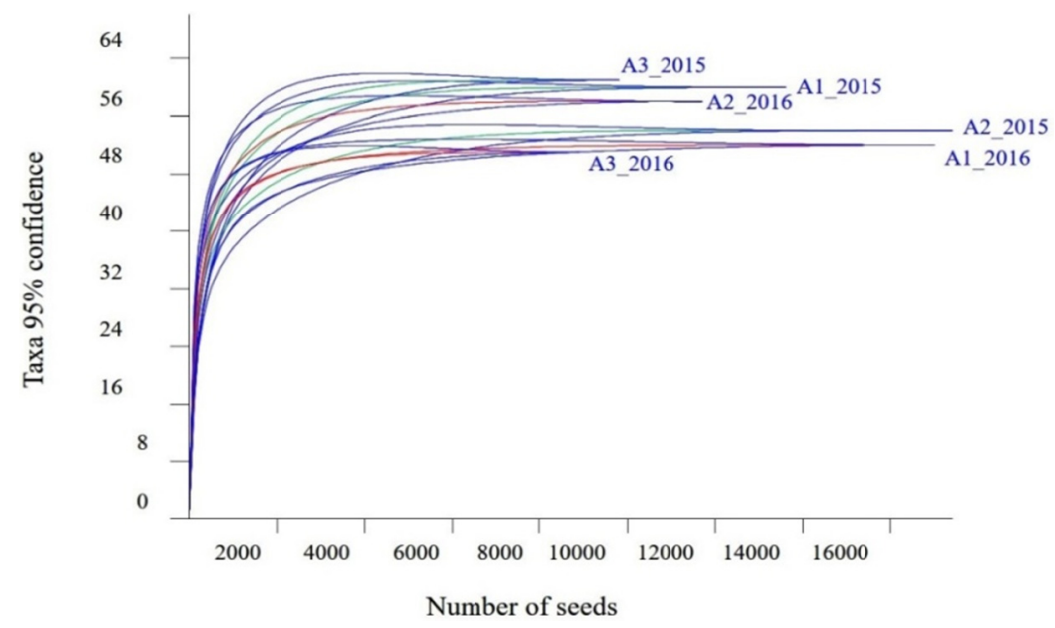

Figure 4. Expected richness in seed rain in 2015 and 2016, in subtropical forest area excluding livestock (A1); cattle stock of 0.5 ua ha $^{-1}$ (A2) and cattle stock of 1.0 ua ha $^{-1}$ (A3), south of Brazil 


\subsection{Floristic Similarity}

The composition of seed rain for the year 2015 presented high similarity between the areas according to the Jaccard index (Figure 5). A1 and A2 were more similar in comparison to A3. In 2016 (Figure 5), A1 and A3 areas presented greater morphospecies similarity in seed rain, although with quite different quantitative contributions from A2.

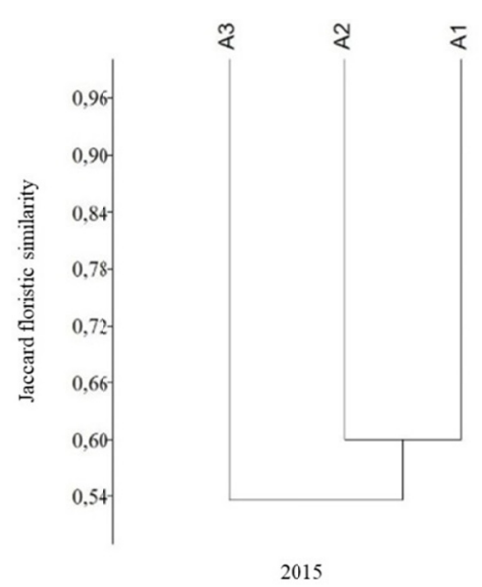

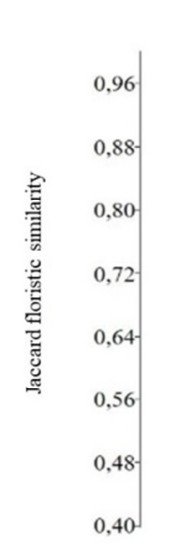

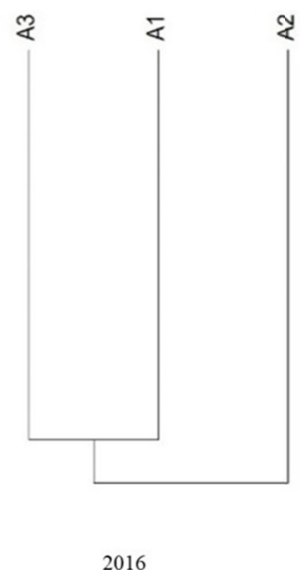

Figure 5. Jaccard floristic similarity for seed rain in 2015 (a) and 2016 (b) in subtropical forest area excluding livestock (A1); cattle stock of 0.5 ua ha $^{-1}$ (A2) and cattle stock of 1.0 ua ha $^{-1}$ (A3), south of Brazil

\section{Discussion}

\subsection{Distribution of Morphospecies}

The highest seed deposition occurred in the months corresponding to the growing season in southern Brazil (September to March) (Figure 2), when the temperature averages do not exceed $22{ }^{\circ} \mathrm{C}$ in spring and are higher than $30^{\circ} \mathrm{C}$ in summer. There is no rain restriction in this period, since the a Cfa climate does not present a dry season (Alvares et al., 2013). The seasonality in the Brazilian subtropics occurs by temperature variation without a dry season, which differs from the seasonality in tropical Brazil (Budke et al., 2005; Venzke et al., 2014; Capellesso et al., 2015).

Regarding the number of seeds per species, we highlighted I. paraguariensis in A1 and A2 areas in 2015. In analyzing the same area, Stefanello (2016) observed low individual sampling of the species in natural regeneration. Considering this information, it is suggested that despite presenting a large number of seeds in the collectors, the species does not present the same abundance of individuals when analyzed in the regeneration of the three study areas. The I. paraguariensis propagules in the seed rain probably come from nearby (allochthonous), since the species presents/displays zoochoric dispersion.

The input and output seed flow between remnants is of great importance, since it is through this flow that we can predict the potential of establishing populations in a certain place (Capellesso et al., 2015; Lopes et al., 2010), especially in areas of natural vegetation that suffer some kind of anthropic interference, as in the case of the present study.

In relation to the temporal distribution in the year 2016 (Figure 2), seed deposition in the winter/spring (July to September) and spring/summer (October to December) periods in the three areas was influenced by local climatic atypicity. According to data from the Instituto Nacional de Meteriologia (IMET), the year 2016 presented an atypical rainfall regime for the region, with precipitation above average in a few months (February, March, April and October, recorded precipitations between 190 and $320 \mathrm{~mm}$ ) and precipitations well below average for other months (January, May, June, July and August). This condition may have contributed to the reduction in the number of collected seedlings and to the period inversion of seed deposition peaks.

There is a record on the influence of the rainfall regime on the phenology of subtropical forest species in southern Brazil (Felippi et al., 2012; Sccoti et al., 2016). In addition, high precipitation can damage to flowers and fruits, also impair the activity of pollinators and dispersers (Jackson, 1978; Kageyama \& Piña-Rodrigues, 
1993). Furthermore, prolonged droughts compromise the reproductive cycle and production of flowers and fruits (Piña-Rodrigues \& Aoki, 2014).

The significant difference between A1 and A3 for the number of seeds in 2016 may be a consequence of an interaction between the climatic atypicality of that year and the intensity of management in A3 (Table 3). In the present study, we observed a decrease in the number of seeds and the number of seeds per hectare, respectively. In addition, the presence of livestock may affect the presence of dispersers due to the diet overlap, modifying floral traits of the existing species (Vázquez, 2002; Eaton et al., 2016). Thus, the higher animal stock for 43 years in A3 contributed to affecting the regeneration mechanisms and altered the vertical structure of the forest, reducing sub-forest strata. This can be verified by the light incidence (Table 1) due to the lower number of plant individuals in the community. The area consequently presents lower resilience and greater susceptibility to environmental variations, such as extreme weather events.

The highest amounts of seeds of arboreal species found in all areas in the two years of evaluation can be considered as a positive indicator. According to Martini and Santos (2007), species of arboreal habitats attract and favor the permanence of pollinating and dispersing animals in the local promoting greater ecological balance in the community.

The number of $C$. trichotoma seeds in the two years of evaluation may be related to the species phenology, since it presents abundant flowering between February and June (Reitz et al., 1988; Felippi et al., 2012). Nevertheless, the species' number of seeds was affected by the atypicality of the precipitation regime in the year 2016. As $C$. trichotoma is a species that occupies the upper strata of the forest formations and presents anemochoric dispersion, its flowers, fruits and seeds are subject to the effects of excessive rainfall. According to Felippi et al. (2012), the species flowers show greater sensitivity in the rainy season due to the impact of raindrops which damage the floral buds, in turn damaging the entire reproductive process.

A. leiocarpa is one of the species with the greatest abundance in the seed rain in 2015 and 2016, and in addition to I. paraguariensis did not present expressivity in the development of the natural regeneration of areas with cattle (A2 and A3), according to a floristic survey carried out in the same areas by Stefanello (2016). It is assumed that these species are more susceptible to the impacts of livestock management, since the development of a species in the regenerating stratum is related to seed rain and is determined by the seed rainfall density and of the seedling density (Simpson, 1989).

\subsection{Scattering Syndrome}

The predominance of zoochory in seasonal forest in southern Brazil (Figure 3), has been reported by several authors (Scipioni et al., 2011; Giehl et al., 2007; Scipioni et al., 2013; Sccoti et al., 2016). This also seems to be a typical pattern of forests in tropical Brazil. According to Fenner (1985) and Piña-Rodrigues and Aoki (2014), the high amount of zoochoric species is indicative of plant communities in more advanced succession stages.

However, finding values between 31 and $37 \%$ of anemochoria in formations with a more advanced succession stage, as in the case of areas A2 and A3, can be a response to the disturbances caused to the vegetation by the cattle management during the four decades. The presence of anemochoria can be considered as an indication of environmental disturbance in already established forest formations, since wind dispersion benefits these conditions (Piña-Rodrigues \& Aoki, 2014). The luminosity values for the respective areas (Table 1) show that the forest cover is more spaced in these places, which would justify the anemochoria values found in this forest formation.

\subsection{Diversity Indices}

There were no significant differences for Shannon diversity in the two years. However, the distribution of morphospecies in A1 for the year 2015 showed to be more heterogeneous in relation to areas with livestock, based on the Pielou evennes index. For the year 2016, A2 showed to be the area with more heterogeneous distribution in relation to the others.

The expected species richness (Figure 4) demonstrates a curve-stabilizing behavior in all areas (Magurran, 2004; Kageyama \& Piña-Rodrigues, 1993; Felfili et al., 2011). In addition, there is an inversion behavior trend of the seed rain from the year 2015 to the year 2016 for the evaluated areas. The seed rain in A2 suffered greater oscillations in relation to the atypical precipitation, probably due to the presence of native field patches in the interior of the sentence fragment (Figure 1). This discontinuity of the forest area in A2 contributes to the action of wind (Giehl et al., 2007) and rain (Vieira \& Gandolfi, 2006; Felippi et al., 2012; Piña-Rodrigues \& Aoki, 2014) in the interior of the forest, unlike A1 and A3, which have a continuous forest formation, considering only the external physiognomy. 


\subsection{Floristic Similarity}

Changes in floristic similarity between the analyzed areas in a short time may be related to several factors; among them climatic factors, such as the case of the atypical precipitation in 2016. Extreme conditions such as excessive rainfall or prolonged droughts with cleared gaps are disturbances that influence the dynamics of the forest community (Giehl et al., 2007) in terms of quantity and quality of flowering and fruiting of species and seed dispersion (Piña-Rodrigues \& Aoki, 2015). These disturbances may directly influence the dissimilarity of areas that may have been closer in floristic terms (Giehl et al., 2007).

In the location under study, we observed that the oscillations in the rainfall regime caused changes in cattle behavior and diet, causing the native field areas surrounding the A2 and A3 areas to decrease their biomass, resulting in a lower supply of food for cattle. This factor may have influenced the animals to look for food inside the forest, intensifying the herbivory and trampling in the local. It also may have contributed to the change in similarity in the evaluation period. The management history and the in loco observations carried out in different years with unequal climatic situations, as in the case of the present study, provide such inferences.

\section{Conclusion}

The presence of cattle within the forest remnant acts effectively as a filter for the dynamics and composition of seed rain.

The higher animal stocking directly impacts the number of seed rain propagules.

Increased stocking reduces ecosystem resilience, making the forest community more susceptible to other disturbances, such as extreme weather events.

\section{References}

Alvares, C. A., Stape, J. L., Sentelhas, P. C., Gonçalves, J. L. M., \& Sparovek, G. (2013). Köppen's climate classification map for Brazil. Meteorologische Zeitschrift, 22, 711-728. https://doi.org/10.1127/ 0941-2948/2013/0507

Araújo, A. C. B., Araujo, H. J. B., Callegaro, R. M., Andrzejewski, C., \& Longhi, S. J. (2017). Estrutura de dois componentes arbóreos de floresta subtropical ripária na campanha gaúcha, Sant'ana do Livramento, RS. Revista Floresta, 46, 481-490. https://doi.org/10.5380/rf.v46i4.42590

Begon, M., Townsend, C. R., \& Harper, J. L. (2016). Ecology: From individuals to ecosystems (4th ed.). Blackwell Publishing.

Brancalion, P. H. S., Garcia, L. C., Loyola, R., Rodrigues, R. R., Pilar, V. D., \& Lewinsohn, T. M. (2016). A critical analysis of the Native Vegetation Protection Law of Brazil (2012): Updates and ongoing initiatives. Natureza \& Conservação, 1-15. https://doi.org/10.1016/j.ncon.2016.03.003

Budke, J. C., Athayde, E. A., Giehl, E. L. H., Záchia, R. A., \& Eisinger, S. M. (2005). Composição florística e estratégias de dispersão de espécies lenhosas em uma floresta ribeirinha, Arroio Passo das Tropas, Santa Maria, RS, Brasil. Iheringia, Série Botânica, Porto Alegre, 60, 17-24.

Capellesso, E. S., Santolin, S. F., \& Zanin, E. M. (2015). Banco e chuva de sementes em área de transição florestal no Sul do Brasil. Revista Árvore, 39, 821-829. https://doi.org/10.1590/0100-67622015000500005

Chazdon, R. L. (2016). Second growth: The promise of tropical forest regeneration in an age of deforestation (p. 472). Universidade de Chicago.

Eaton, D. P., Keuroghlian, A., Santos, M. C., Desbiez, A. L. J., \& Sada, D. (2016). Citizen scientists help unravel the nature of cattle impacts on native mammals and birds visiting fruiting trees in Brazil's southern Pantanal. Biological Conservation, 1-11. https://doi.org/10.1016/j.biocon.2016.09.010

EMBRAPA (Empresa Brasileira de Pesquisa Agropecuária). (2013). Sistema brasileiro de classificação de solos (3rd ed., p. 353). Brasília.

Equipe Estatcamp. (2014). Software Action, Estatcamp-Consultoria em estatística e qualidade. São Carlos-SP, Brazil.

Felfili, J. M., Carvalho, F. A., Libano, A. M., Venturoli, F., Pereira, B. A. S., \& Machado, E. L. M. (2011). Análise multivariada: princípios e métodos em estudos de vegetação. In J. M. Felfili (Ed.), Fitossociologia no Brasil: métodos e estudos de caso (Vol. I, pp. 122-155). Viçosa, MG, UFV. 
Felippi, M., Maffra, C. R. B., Cantarelli, E. B., Araujo, M. M., \& Longhi, S. J. (2012). Fenologia, morfologia e análise de sementes de Cordia trichotoma (Vell.) Arráb. ex Steud. Ciência Florestal, 22, 631-641. https://doi.org/10.5902/198050986629

Fenner, M. (1985). Seed ecology (p. 147). London, Chapman and Hall. https://doi.org/10.1007/ 978-94-009-4844-0

Giehl, E. L. H., Athayde, E. A., Budke, J. C., Gesing, J. P. A., Eisinger, S. M., \& Canto-Dorow, T. S. (2007). Espectro e distribuição vertical das estratégias de dispersão de diásporos do componente arbóreo em uma Floresta Estacional no sul do Brasil. Acta Botânica Brasilica, 21, 137-145. https://doi.org/10.1590/ S0102-33062007000100013

Gotelli, N. J., \& Colwell, R. K. (2001). Quantifying biodiversity: Procedures and pitfalls in the measurement and comparison of species richness. Ecological Letters, 4, 379-391. https://oi.org/10.1046/ j.1461-0248.2001.00230.x

Hammer, O., Harper, D. A. T., \& Ryan, P. D. (2001). Past: Paleontological Statistics software package for education and data analysis. Palaeontologia Electronica, 4, 1-9.

Hutcheson, K. A. (1970). Test for comparing diversities based on the Shannon formula. Journal Theory Biology, 29, 151-154. https://doi.org/10.1016/0022-5193(70)90124-4

Hutchings, M. J. (1989). The Structure of Plant Populations. In M. Crawley (Ed.), Plant Ecology (pp. 97-136). Blackwell Scientific Publications, Oxford, London.

IBGE (Instituto Brasileiro de Geografia e Estatística). (2014). Senso Municipais, Rio Grande do Sul. Brasília. Retrieved from https://www.ibge.gov.br/estatisticas-novoportal/por-cidade-estado-estatisticas.html

INMET (Instituto Nacional de Meteorologia). (2017). Dados meteorológicos. Retrieved from http://www.inmet.gov.br

Jackson, J. F. (1978). Seasonality of flowering and leaf fall in a Brazilian subtropical lower montane moist forest. Biotropica, 10, 38-42. https://doi.org/10.2307/2388103

Kageyama, P. Y., \& Piña-Rodrigues, F. C. M. (1993). Fatores que afetam a produção de sementes. In I. B. Aguiar, F. C. M. Piña-Rodrigues, \& M. D. Figliolio (Eds.), Sementes tropicais florestais (pp. 19-46). Brasília, Abrates.

Lopes, S. F., Oliveira, A. P., Neves, S. B., \& Schiavini, I. (2010). Dispersão de sementes de uruvalheira (Platypodium elegans VOG) (Fabaceae) em um Cerrado, Uberlândia, MG. Revista Árvore, 34, 807-813. https://doi.org/10.1590/S0100-67622010000500006

Magurran, A. E. (2004). Measuring biological diversity (p. 256). Blackwell, Oxford.

Marchiori, J. N. C. (2004). Fitogeografia do Rio Grande do Sul: Campos Sulinos (p. 110). Porto Alegre, EST.

Martini, A. M. Z., \& Santos, F. A. M. (2007). Effects of distinct types of disturbance on seed rain in the Atlantic forest of NE. Brazil. Plant Ecology, 190, 81-95. https://doi.org/10.1007/s11258-006-9192-6

Michels, G. H., Vieira, E. M., \& SÁ, F. N. (2012). Short and long-term impacts of an introduced large herbivore (Buffalo, Bubalus bubalis L.) on a neotropical seasonal forest. European Journal of Forest Research, 131, 965-976. https://doi.org/10.1007/s10342-011-0568-3

Müeller-Dombois, D., \& Ellenberg, H. (1974). Aims and Methods of Vegetation Ecology (p. 547). New York, John Wiley \& Sons.

Pillar, V. D., \& Quadros, F. L. F. (1997). Grassland-forest boundaries in southern Brazil. Coenoses, 12, $119-126$.

Piña-Rodrigues, F. C. M., \& Aoki, J. (2014). Chuva de sementes como indicadora do estádio de conservação de fragmentos florestais em Sorocaba, SP. Ciência Florestal, 24, 911-923. https://doi.org/10.5902/ 1980509816603

Reitz, R., Klein, R. M., \& Reis, A. (1988). Projeto madeira do Rio Grande do Sul (p. 525). Porto Alegre, Secretaria de Estado da Agricultura e Abastecimento.

Roesch, L. F., Vieira, F., Pereira, V., Schünemann, A. L., Teixeira, I., Senna, A. J., \& Stefenon, V. M. (2009). The Brazilian Pampa: A Fragile Biome. Diversity, 1, 182-198. https://doi.org/10.3390/d1020182

Rovedder, A. P. M., Piazza, E. M., Thomas, P. A., Felker, R. M., Hummel, R. B., \& Farias, J. A. (2016). Potential medicinal use of forest species of the Deciduous Seasonal Forest from Atlantic Forest Biome, 
South Brazil. Brazilian Archives of Biology and Technology, 59, 1-11. https://doi.org/10.1590/1678-43242016150329

Sampaio, M. B., \& Guarino, E. S. G. (2007). Efeitos do pastoreio de bovinos na estrutura populacional de plantas em fragmentos de floresta Ombrófila Mista. Árvore, 31, 1035-1046. https://doi.org/10.1590/ S0100-67622007000600008

Sccoti, M. S. V., Araujo, M. M., Tonetto, T. S., \& Longhi, S. J. (2016). Dinâmica da chuva de sementes em remanescente de floresta estacional subtropical. Ciência Florestal, 26, 1179. https://doi.org/10.5902/ 1980509825109

Scipioni, M. C., Finger, C. A. G., Cantarelli, E. B., Denardi, L., \& Meyer, E. A. (2011). Fitossociologia em fragmento florestal no noroeste do estado do Rio Grande do Sul. Ciência Florestal, 21, 409-419. https://doi.org/10.5902/198050983799

Scipioni, M. C., Galvão, F., \& Longhi, S. J. (2013). Composição florística e estratégias de dispersão e regeneração de grupos florísticos em Florestas Estacionais Deciduais no Rio Grande do Sul. Floresta, 43, 241-254. https://doi.org/10.5380/rf.v43i2.27098

Silveira, V. C. P., González, J. A. D. A., \& Fonseca, E. L. (2017). Land use changes after the period commodities rising price in the Rio Grande do Sul State, Brazil. Ciência Rural, 47, e20160647. https://doi.org/10.1590/0103-8478cr20160647

Simpson, R. L. (1989). Ecology of soil seed bank (pp. 257-281). San Diego, CA, USA, Academic Press.

Stefanello, M. M. (2016). Influência da pecuária bovina nos mecanismos de regeneração da Floresta Estacional Decidual, Rio Grande do Sul, Brasil (Dissertação de mestrado, Universidade Federal de Santa Maria, RS).

Streck, E. V., Kampf, N., Dalmolin, R. S. D., Klamt, E., Nascimento, P. C., Giasson, E., \& Pinto, L. F. S. (2018). Solos do Rio Grande do Sul (3rd ed., p. 251). UFRGS, EMATER/RS-ASCAR, Porto Alegre.

Van, D. P. (1982). Principles of dispersal in higher plants (3rd ed., p. 323). New York, Springer-Verlag.

Vázquez, D. P., \& Simberloff, D. (2002). Ecological specialization and susceptibility to disturbance: Conjectures and refutations. American Naturalist, 159, 606-623. https://doi.org/10.1086/339991

Venzke, T. S., Martins, S. V., Neri, A. V., \& Kunz, S. (2014). Síndromes de dispersão de sementes em estágios sucessionais de mata ciliar, no extremo sul da Mata Atlântica, Arroio do Padre, RS, Brasil. Árvore, 38, 403-413. https://doi.org/10.1590/S0100-67622014000300002

Vieira, D. C. M. (2006). Gandolfi, S. Chuva de sementes e regeneração natural sob três espécies arbóreas em uma floresta em processo de restauração. Revista Brasileira de Botânica, 29, 541-554. https://doi.org/ $10.1590 / \mathrm{S} 0100-84042006000400004$

\section{Copyrights}

Copyright for this article is retained by the author(s), with first publication rights granted to the journal.

This is an open-access article distributed under the terms and conditions of the Creative Commons Attribution license (http://creativecommons.org/licenses/by/4.0/). 